\title{
KOLONIZACJA I CHRYSTIANIZACJA A TEATR - SPOJRZENIE Z PERSPEKTYWY XX I XXI WIEKU
}

\author{
Maria Delimata \\ maria.delimata@gmail.com
}

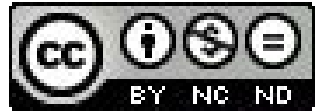

Z dzisiejszej perspektywy widać, że czas dumnie nazywany okresem „wielkich odkryć geograficznych" zapisał się wieloma czarnymi kartami w historii Europy. Pod płaszczem niesienia Słowa Bożego i cywilizacji dla Nowych Ziem najczęściej kryła się chęć wzbogacenia europejskich mocarstw, a „postęp” i „rozwój kulturalny” okupiony został krwią i cierpieniem niezliczonej ilości osób. Taki obraz zyskujemy po przestudiowaniu relacji historycznych, opracowań naukowych, a przede wszystkim, dzięki fermentowi, jaki wniósł rozwój teorii postkolonialnej w drugiej połowie XX wieku.

Tematem tego artykułu nie jest jednak przedstawienie kilkusetletniej historii kolonizacji zamorskiej, a tym bardziej jej moralna ocena. Wydaje się, że w tej kwestii wystarczająco dużo zostało już powiedziane. Sformułowanie aktu oskarżenia i udowodnienie winy nie przyniosło zapewne oczyszczenia, ani zadośćuczynienia, otworzyło jednak przestrzeń międzynarodowej, społecznej dyskusji nad historia, tradycją i kulturą europejską - na zawsze odartą już z szaty niewinności.

Moją propozycją jest zatem interpretacyjne „zawieszenie broni” - refleksja nie nad tym, kto ma rację: badacze oskarżający Hiszpanię o zniszczenie z pełną premedytacją cywilizacji Azteków, czy też historyk Arnold Toynbee, formułujący tezę, iż hiszpańscy misjonarze nigdy nie zmuszali autochtonów do porzucenia lokalnych tradycji, a fakt opracowania przez nich gramatyki, składni i transkrypcji języków quechua, nahuatl, guarani, czy tarasque, otacza ich nimbem chwały.

Przyjmijmy status quo - stan, w którym granica między tym, co czarne a tym, co białe (w najjaskrawszych odcieniach tych barw) jest płynna i dychotomiczna. Spójrzmy obiektywne (o ile to możliwe!) na rytuały i widowiska, które nigdy nie narodziłyby się bez kolonizacji i nie przyjęłyby obecnego kształtu bez procesu walki o postkolonialną wolność.

Chociaż przepracowywanie traumy przez byłych skolonizowanych dokonywało się przede wszystkim na terenie literatury, która daje szansę (re)konstruowania tożsamości narodowej, proponuję przyjrzeć się problemom kolonizacji i postkolonializmu z innej perspektywy - a mianowicie: przez pryzmat teatru i widowisk, kładąc przy tym szczególny nacisk na kwestie związane ze sferą religijności. Moim celem jest dostrzeżenie w omawianych teatrach, widowiskach, rytuałach i performansach postkolonialną hybrydę - która nigdy nie powstałaby bez prekolonialnych korzeni, kolonizacyjno-chrystianizacyjnej działalności misjonarzy oraz postkolonialnego Nowego Porządku.

Zachodnia refleksja nad sakralnością teatru często doszukiwała się w nim odbicia relacji Bóg-człowiek. Postrzegano stwórczą zdolność teatru jako powtórzenie stwórczego gestu Boga ${ }^{1}$, wskazywano też na charakter dzieła teatralnego jako „największego świeckiego wysiłku człowieka, by stać się obrazem Boga" ${ }^{2}$. Nierzadko zauważano też powiązania pomiędzy wzrostem zainteresowania dawnym dramatem i teatrem liturgicznym/sakralnym (także we współczesnych nawiązaniach do tej tradycji) a falą zainteresowania tzw. teatrem Wschodu (gdzie słowo i rytuał miałyby mieć funkcję prymarną).

Por. I. Sławińska, Dramat i teatr w refleksji teologicznej, [w:] I. Sławińska, W. Kaczmarek, W. Sulisz, M. B. Stykowa (red.), Dramat i teatr sakralny, Lublin 1988, s. 17.

2 H. Gouhier, Istota teatru. Obecność i teraźniejszosćć, „Pamętnik Literacki” 1976, z. 2, s. 16. 
Przykłady, które chciałabym zaprezentować - iztapalapiańska pasja, filipińskie widowiska i performanse sakralne oraz jawajski teatr cieni wayang wahyu - w swojej relacji z Bogiem, z sacrum, wymagają odmiennych narzędzi interpretacyjnych. Nieprecyzyjne jest zamykanie ich jedynie w europejskich formułach "teatru” czy „widowiska” (często bliżej im bowiem do „performansu sakralnego", hybrydycznej konstrukcji łączącej teatralność, widowiskowość i performatyczny kontakt z sacrum), a tym bardziej określanie mianem „orientalnych" - z pominięciem splotu trzech punktów czasowych (pre-przeszłości, przeszłości i teraźniejszości), bez którego nigdy nie przybrałyby dzisiejszego, hybrydycznego kształtu.

\section{Orientalna KOlOnizacja}

Nim przejdziemy do opisu działalności i wpływu chrześcijańskich misjonarzy, warto zburzyć pokutujący w wielu dyskusjach na temat postkolonializmu mit, mówiący o tym, iż Europejczycy przybyli na tereny o ukonstytuowanej od wieków czystej i autochtonicznej kulturze danego nie-europejskiego państwa. Jak w przypadku każdego obszaru, na którym spotykają się ludzie mówiący różnymi językami, a tym bardziej wyznający odmienne religie, dochodzi do długofalowej wymiany i wzajemnej interferencji systemu pojęć i wartości, co najwyraziściej przejawia się w takich aspektach jak: mitologia, rytualność, literatura, muzyka, teatr, czy nawet architektura.

Oczywiście niezbędne jest przy tym zaznaczenie, iż jeden sposób kolonizacji nie jest równy drugiemu i to przede wszystkim polityka, określająca ramy danej kolonizacji, decyduje o tym, na ile kultura poddana wpływowi „,z zewnątrz", zostanie wzbogacona lub zniszczona.

Jest to szczególnie widoczne w przypadku państw wyspiarskich Azji Południowo-Wschodniej (niestety, nawet dziś jesteśmy skazani na operowanie tym europocentrycznym terminem) - a zatem przestrzeni w tym samym stopniu otwartych, co zamkniętych. I tak trudno byłoby w pełni zrozumieć teatr rytualny filipińskiej wyspy Mindanao i wysp Sulu, bez wpływu tradycji malezyjskiej czy indonezyjskiej (nim 7. kwietnia 1521 r. do dzisiejszego Cebu przybiły statki Ferdynanda Magellana, rozpoczynając tym samym kilkusetletnią kolonizację Filipin, połączoną z procesem tworzenia z archipelagu wysp jednego państwa, zarządzanego przez Królestwo Hiszpanii, południowa część dzisiejszych Filip znajdowała się pod wpływem sułtanatu indonezyjskiego), jak i niemożliwe byłoby zrozumienie indonezyjskiego wayang kulit bez wpływu hinduizmu i buddyzmu, przyniesionych m.in. z Indii.

Warto w tym miejscu przytoczyć wypowiedź George’a Blonda, który pokazał, iż „Indie nie miały żadnego powodu, by zakładać kolonie lub prowadzić ekspansjonistyczną politykę, gdyż nie potrzebowały gotówki. Dostarczano im wszystkiego, czego potrzebowały, w zamian za niewielką część ich bogactw. Przybywano nawet z Dalekiego Wschodu w poszukiwaniu kapłanów. To bramini pokonywali jako pierwsi szlak morski łączący Indie z Indonezją. Europo, skryj twarz ze wstydu -kapłanom tym nie towarzyszyli żołnierze i kupcy, lecz artyści i architekci. Świątynie Angkor w Kambodży i Borobudur na Jawie, a także wiele innych, powstały dzięki pracy architektów przybyłych z Indii oraz uczniów, których wykształcili już na miejscu. Spróbujmy znaleźć doskonalszą formę »kolonizacjiı" ${ }^{\prime \prime}$.

Jak powszechnie wiadomo strategia europejskiej kolonizacji wyglądała zgoła odmiennie. Frederick Lugard - brytyjski żołnierz i kolonizacyjny administrator Korony Brytyjskiej Hong Kongu (1907-1912) oraz Nigerii (1914-1919) w dokumencie, pochodzącym z początku XX w., zatytułowanym The Value of British Rule in the Tropics to British Democracy and the Native Races tak

3 G. Blond, Ocean przygody, t. 2,Warszawa 2008, s. 29. 
opisywał kolonizacyjną „,misję": „tak jak rzymskie imperium ufundowało podstawy współczesnej cywilizacji i przeprowadziło dzikich barbarzyńców tych wysp przez ścieżkę sukcesu, tak i my dziś spłacamy ten dług w Afryce, przynosząc na te ciemne miejsca Ziemi, zamieszkane przez barbarzyństwo i okrucieństwo, pochodnię kultury i postępu, służącjednocześnie materialnym potrzebom naszej cywilizacji. W zadaniu tym narody Europy uroczyście ślubowały sobie pomoc. Dla osiagnięcia wspólnego celu każdy będzie stosować metody najbardziej zgodne ze swoim narodowym duchem. [...] Jeśli w Indiach i Egipcie, pojawia się niepokój i żądanie niezależności, to dlatego, iż nauczyliśmy ich wartości wolności i swobody, których przez wieki ludzie ci nie znali. Ich olbrzymie niezadowolenie jest miarą postępu. Panujemy nad tymi krajami dzięki geniuszowi naszej rasy, który pozwala kolonizować, [rozwijać] handel i zarządzać" ${ }^{\prime \prime 4}$.

\section{DWA WULKANY: JEZUICKA ZMIANA PARADYGMATU TEATRALNEGO}

I Sobór WATYKańsKi II

Działalność misjonarzy - a w szczególności jezuitów - pokazuje, jak silnie zmienił się paradygmat postrzegania istoty teatru. Przez setki lat teatr był bowiem obłożony kościelną „klątwą”, później zaś stał się jednym z najczęściej wykorzystywanych narzędzi w procesie chrystianizacji.

Nie wolno zapominać o tym, iż nie tylko zakon jezuicki wykorzystywał "teatralną strategię" na terenie Nowych Ziem, jednak ani franciszkanie, ani augustianie (biorący udział w chrystianizacji m.in. Meksyku czy Chin) nie odnieśli tak wyraźnego sukcesu.

W drugiej połowie XVI w. Towarzystwo Jezusowe stworzyło tradycję tzw. „,dramatu jezuickiego", a zatem widowiska scenicznego, granego po łacinie przede wszystkim w prowadzonych przez nie kolegiach. Tematy biblijne i hagiograficzne - ujęte $\mathrm{w}$ teatralną formę - były nieocenionym narzędziem edukacyjnym i chrystianizacyjnym i aż do kasaty zakonu w 1773 r. teatr jezuicki stanowił jeden z najważniejszych filarów europejskiego (także polskiego) teatru.

Kolonizacyjny i misjonarski sukces jezuitów nie byłby zapewne możliwy bez tak znakomicie rozwiniętej strategii kulturalnej.

Jean Lacouture w Jezuitach - jednej z najważniejszych publikacji na temat historii i działalności kontynuatorów misji Ignacego Loyoli - zwrócił uwagę na fakt, iż siła zakonu tkwiła w jego humanistycznych fundamentach. „Prawda, że uporczywie trzyma się legenda o Towarzystwie Jezusowym stanowiącym jakby zastęp żołdaków o niskich czołach, papieskie komando, któremu przewodził Loyola - żołnierz atakujący Reformę, przezeń poskramiana, o ile nie odpieraną... Legenda ta jest tak uporczywa i nawracająca, że aż prosi się, by przeciwstawić jej odwrotną hipotezę, ukazującą pierwszą grupę „inigistów” jako bractwo żaków olśnionych przez wielkie umysły, które uczyniły z Paryża za czasów Franciszka I intelektualny ośrodek Zachodu, a przekształcone w Towarzystwo Jezusowe wskutek nieomal samorzutnego zapłodnienia przez niezwykle twórcze środowisko, poddane bezprecedensowemu fermentowi duchowemu i intelektualnemu" ${ }^{\prime \prime}$.

I właśnie taką „odwrotną perspektywę" Lacouture roztacza przed oczami czytelnika na kilkudziesięciu stronach rozdziału zatytułowanego Żacy z Montmartre'u. Celem nie jest jedynie obalenie stereotypowych wyobrażeń o korzeniach Towarzystwa Jezusowego, lecz także zbudowanie spójnej wizji, w której jezuici przez kilkaset lat konsekwentnie wypełniali swoją chrystianizacyjną misję. „Zakon stworzony przez włóczęgę, jest z gruntu włóczęgowski. Jego pierwsze sanktuaria - Manresa, Montmartre, La Storta, leżą na skraju drogi. Pierwszą parafią rzymską jest

4 L. Frederick, The Value of British Rule in the Tropics to British Democracy and the Native Races, [w:] G. Desai, S. Nair (red.), Postcolonialism. An Anthology of Cultural Theory and Criticism, Oxford 2005, s. 35.

5 J. Lacouture, Jezuici, t. 1: Zdobywcy, Warszawa 1998, s. 47. 
Santa Maria della Strada - czyli Matka Boża Przydrożna... Mimo że jezuickie kolegia zakładano w samym sercu dominującej i dobrze rozwiniętej cywilizacji Zachodu, zakon nie zaprzestanie szukać szczęścia i nieszczęścia na pełnym morzu, od Filipin po Peru"6.

W kontekście misjonarskiej kolonizacji kolejnym punktem zwrotnym okazał się Sobór Watykański II (1962-1965), promujący inkulturacyjną misję Kościoła katolickiego. Co istotne, wskazania na jego doniosłą rolę wysuwają nie tylko naukowcy „z zewnątrz”, zajmujący się XX-wiecznym obliczem kultury krajów postkolonialnych, lecz przede wszystkim ci, którzy starają się poddać redefinicji kulturę, do której należą. Doskonałym przykładem może być dyskusja, która rozgorzała podczas konferencji na ten temat, zorganizowanej w Manili w czerwcu $1991 \mathrm{r}$. przez Institute on Church and Social Issues Ateneo de Manila oraz Institute on Church and Social Issues Loyola School of Theology.

Kwestia zmiany, wynikająca z postanowień Vaticanum II zostanie jeszcze szerzej opisana w dalszej części artykułu.

\section{Meksykańska Pasja}

Gdy w 1524 r. do dzisiejszego Meksyku przybyli misjonarze, towarzyszący żołnierzom Cortésa, nie przywieźli ze sobą inscenizacji pasji Chrystusa tylko z jednego powodu - ponieważ $\mathrm{w}$ tamtym czasie taka tradycja w Hiszpanii nie istniała. To, co jednak stanowiło niezaprzeczalnie silny instrument, ułatwiający chrystianizację, to tradycja (samo-) biczowań (której fala wcześniej przetoczyla się przez całą średniowieczną Europę). To właśnie tutaj rozpoczął się proces, który rozprzestrzenił się później na całą strefę wpływów hiszpańskich misjonarzy - na Filipiny, Japonię, czy Chiny ${ }^{7}$.

Jak pokazuje Richard C. Trexler, w książce Reliving Golgotha. The Passion Play of Iztapalapa „duchowieństwo przybyło z [określoną] strategią i to ich rozmyślna manifestacja samoumartwiania wywarła największy wpływ na tubylców, od tamtego czasu [I poł. XVI w. - przyp. M.D.] aż do XVIII wieku"s.

Co istotne, na początku rolę Jezusa mogli „odgrywać” jedynie Hiszpanie (najczęściej, choć nie zawsze, byli to zakonnicy). Indianie przyjmowali jedynie role tych, którzy umęczali jego ciało (zatem Żydów - którzy w tamtym czasie w Hiszpanii byli już napiętnowani). Jak widać, bardzo klarownie zarysowywał się przy tym hierarchiczny podział ról, znajdujący przełożenie na ogólne relacje, panujące między uczącymi a nauczanymi wiary chrześcijańskiej.

R. Trexler niezwykle precyzyjnie opisał historię i proces transformacji chrystianizacyjnych praktyk, balansujących na granicy teatru, widowisk i rytuałów, od momentu przybycia Hiszpanów na teren dzisiejszego Meksyku aż do współczesności. Początkowo wszelkie formy mimetycznego powtarzania, performatywnego „,odgrywania” chrystusowej męki, były wykonywane przez hiszpańskich misjonarzy w odniesieniu do zredefiniowanych przez nich słów Jezusa: „Czyńcie to na moją pamiątkę" . Ewangeliczne nauczanie, przekazywanie biblijnych historii i doktryn Kościoła katolickiego stapiało się z jak najbardziej dosłownym umęczaniem swojego ciała poprzez publiczne biczowania, czy chodzenie po rozżarzonych węglach (przez takich XVI- i XVII-wiecznych augustianów-misjonarzy, jak Juan de Grijalva, czy Antonio de Roa) $)^{10}$. Tak rozumiana forma chry-

6 Tamże, s. 106.

Por. R. C. Trexler, Reliving Golgotha. The Passion Play of Iztapalapa, Cambridge, Massachusetts, London 2003, s. 24

Por. tamże, s. 25

Tamże, s. 9.

10 Por. tamże, s. 26. 
stianizacji stanowiła doskonały fundament dla dalszego rozwoju tradycji pasyjnych. Jedną z nich - prawdopodobnie najważniejszą i najbardziej rozpoznawalną na świecie - jest pasja odbywająca się corocznie w jednej z szesnastu dzielnic Dystryktu Federalnego miasta Meksyk - Iztapalapie.

Nie sposób ustalić daty pierwszej inscenizacji Pasji w Iztapalapie. Według Trexlera, najbardziej prawdopodobny jest rok 1843 lub 1844. Należy jednak zaznaczyć, iż tradycja pasyjna, była obecna znacznie wcześniej, na co wskazują działania podjęte przez arcybiskupa Meksyku w 1769 r., które miały na celu zakazanie widowisk, tzw. neixquitiles, organizowanych już nie przez duchowieństwo, lecz „Indian z Nowej Hiszpanii”"11.

Odgrywanie pasji Chrystusa w Iztapalapie było reakcją na epidemię cholery w 1833 r., która zdziesiątkowała miasto. Odegranie śmierci Chrystusa było formą dziękczynienia i jednocześnie przebłagania Boga - a tym samym stało się splotem tego, co „rdzenne”, „podświadome” (potrzeba wejścia w interakcję z Istotą Wyższa, mająca wpływ na ludzkie życie) a formami kultu wprowadzonymi przez katolickich misjonarzy.

Początkowo w widowisku nie używano kostiumów, ani koni, jednak z roku na rok coraz lepiej dopracowywano formę tak, by „„sugestywniej” wyrażała emocje i uczucia religijne, panujące w sercach wiernych, m.in. poprzez rzeczywiste opłakiwanie i (współ-) cierpienie z konającym Chrystusem ${ }^{12}$.

W ciagu następnego półtora wieku tradycja ta była szeroko rozwijana również pod wpływem zmian politycznych i społecznych. Odkryto, iż teatralnie wyrażana sakralność może dawać obietnicę ucieczki od melancholii i przepracowywania historycznej, jak i socjologicznej traumy. Stan, jaki można dziś zaobserwować wśród ludności miasta Meksyk, pokazuje wyraźną granicę między klasą społeczną średnią i wyższą a niższą. Pierwsza celebruje zmartwychwstanie Chrystusa, druga zaś - jego cierpienie i śmierć, która dopiero zapowiada rezurekcyjno-triumfalistyczny finał w przyszłości ${ }^{13}$.

Co istotne, widowiska, które możemy współcześnie oglądać, oparte są nie na Biblii, lecz na tekście Pérez Escricha ${ }^{14}$. Sacrum zostało zatem poddane procesowi dramatyzacji, czy też udramatyzowieniu. Kontakt z tym, co boskie odbywa się poprzez filtrację religii na język teatralny.

Co podkreślał Trexler „CComité Organizador dawniej i dziś modyfikowało tekst, wykreślając ten, bądź inny fragment, jeśli wydawał się mniej atrakcyjny dla publiczności. [...] Zaiste, często zwracano uwage, iż takie modyfikacje czyniły przedstawienie „,bardziej realistycznym”, ale tak naprawdę na pierwszym miejscu często była stawiana decyzja, by prezentować istotną, współczesną sytuację społeczną"15.

W każdy Wielki Czwartek Jezus (a dokładnie osoba wcielająca się w jego rolę - od kilku lat jest to Andrés Espinosa) kroczy ulicami Iztapalapy. Zatrzymują go osoby proszące o cud nie jest to już jednak forma gry, lecz quasi-modlitwa - prawdziwe, przesączone wiarą błaganie Boga. Espinosa nie jest już jedynie aktorem, lecz pośrednikiem między ludem a Bogiem. Choć w wywiadach proszący przyznaja że doskonale wiedza, iż mówią do człowieka, który przez kilka dni Semana Santa tylko odgrywa Chrystusa, wierzą jednak, iż tak sformułowana prośba, wraz z ich uczestnictwem w religijnej fieście, może przynieść konkretne rezultaty ${ }^{16}$.

\footnotetext{
1 Tamże, s. 67.

2 Por. http://www.inside-mexico.com/featuresemana.htm, 8.11.2010.

R. C. Trexler, Reliving..., dz. cyt., s. 220.

Por. tamże, s. 218.

Por. tamże.

16 Por. „„»Proszę, Panie, ześlij cud « powiedziała Hilaria, której 59-letni mąż jest bardzo chory i potrzebuje pomocy. Hilaria, miejscowa pulchna kobieta, dodała, że pomimo świadomości, iż postać Chrystusa odgrywał aktor, jest pewna, że jej stosowanie się do katolickich tradycji i wierzeń pomoże w uzyskaniu cudu, podobnie jak to się stało rok wcześniej, gdy prosiła w swojej intencji”. http://ipsnews.net/interna.asp?idnews=23257, 9.11.2010.
} 
Co więcej, wielu aktorów podejmuje swą rolę z „boskiego polecenia”. Carlos Martínez wyznał dziennikarzom: „Bóg wskazał mi tę drogę i dlatego jestem tu, by grać Rzymianina, który umęcza Jezusa"17. Martí Santiago, podejmujący tę samą rolę co Martínez, powiedział, iż Bóg przemówił do niego we śnie, aby ten wziął udział w sakralnym przedstawieniu i podążał za Chrystusem, by pozostać zdrowym ${ }^{18}$.

Przyjęcie na siebie jakiejkolwiek roli w iztapalapiańskiej pasji wiąże się nie tylko z określonymi cechami moralnymi i religijnymi, jakie musi posiadać dana osoba, lecz także z predyspozycjami fizycznymi. Uczestnictwo jest prawdziwym wyróżnieniem, jednak równie istotne wydają się świetna kondycja i siła fizyczna (by wytrzymać ból biczowania oraz ciężar kilkumetrowego drewnianego krzyża).

„Oryginalność" iztapalapiańskiej Via Crucis polega także na jeszcze jednym elemencie wplecionym w wielkotygodniowe widowisko - procesji Nazareńczyków. W przeciwieństwie do ról Jezusa czy Maryi, nie jest tu wymagane iztapalapiańskie pochodzenie, lecz wewnętrzna potrzeba odby cia drogi - uteatralizowanej, lecz wciąż głęboko sakralnej.

Nazareńczycy (niezależnie od wieku, czy regionu, z którego pochodzą) muszą wyglądać tak samo: ubrani są w purpurową tunikę, ich głowę okala cierniowa korona, a na plecach niosą olbrzymi krzyż. W ten sposób wypełniają swoją mandę - obietnicę złożoną Bogu, by podziękować mu za uleczenie, przeżycie groźnego wypadku, znalezienie pracy, czy też przebłaganie go za grzechy ${ }^{19}$.

Gdy iztapalapiańska pasja wzbudziła w XX wieku zainteresowanie mediów (a tym samym turystów - dzięki czemu COSSIAC, Comité Organizador de Semana Santa en Iztapalapa AC, otrzymuje dziś regularne wsparcie rządu meksykańskiego ${ }^{20}$ ) zaczęto wskazywać na skomercjalizowanie się religijnego wydarzenia. Główne oskarżenia skupiały się na rzekomym fakcie przekroczenia pewnej granicy w zachowaniu publiczności (desbordado) i „,groteskowości" działań aktorów²1.

Od kilku lat meksykański Kościół katolicki utrzymuje, iż iztapalapiańska pasja jest je d y n i e teatrem i - choć jest to działalność godna szacunku - to nie może uzyskać zgody Kościoła. Jest to sytuacja kuriozalna, tym bardziej, że część katolickich księży nie tylko corocznie bierze udział w tym wydarzeniu, lecz także błogosławi aktorów, nim ci wyruszą w uteatralnionej procesji2²

Ten fundamentalny konflikt między stanowiskiem duchowieństwa a niższą klasą społeczną miasta Meksyk pokazuje wyraźną granicę między dwoma sposobami przeżywania sakralności, a jednocześnie podejściem do postkolonialnego dziedzictwa chrystianizacji poprzez teatr. Sakralna mimesis w odczuciu iztapalapiańskiej społeczności z definicji musi być teatralna ${ }^{23}$.

\section{FILIPINY - ANIMIZM, KATOLICYZM I (POSTAMERYKAŃSKA) SEKULARYZACJA}

Jak w przypadku wielu krajów w tej części świata, Filipiny zyskały swoją państwowość w wyniku kolonizacji (i oczywiście późniejszej walki o niepodległość), a bez działalności misjonarzy, współdziałających z hiszpańskimi żołnierzami, nie byłyby jedynym miejscem w Azji Południowo-Wschodniej, gdzie religią dominująca jest katolicyzm. Fakt ten stanowi jeden z najtrudniejszych wyzwań w dzisiejszej dyskusji, jaka toczy się w tym państwie, na temat tożsamości narodowej Filipińczyków. Jednocześnie konflikt wewnętrzny, który sprawia, że nie tylko na

\footnotetext{
17 Tamże.

18 Tamże.

19 Por. http://www.inside-mexico.com/featuresemana.htm, 8.11.2010.

$20 \quad$ R. C. Trexler, Reliving..., dz. cyt., s. 217.

21 Tamże, s. 219.

22 Por. http://ipsnews.net/interna.asp?idnews=23257, 9.11.2010.

23 R. C. Trexler, Reliving ..., dz. cyt., s. 220.
} 
południu kraju (Mindanao), lecz także w stolicy, Manili, i dziś wybuchają bomby, jest skutkiem nie zawsze prostej koegzystencji chrześcijańskiej większości i islamskiej mniejszości religijnej.

Współcześnie coraz więcej Filipińczyków określa siebie jako niewierzących, lub też „wierzących niepraktykujących" - a jednak każda publiczna debata, poświęcona tożsamości, dotyka silnego związku łączącego "filipińskość" i "katolickość" omawianego tu narodu. Przykładem tego może być wspominana już wcześniej konferencja Integrative or divise? Christian Symbols and Rituals in Philippine Society, która odbyła się na uniwersytecie Ateneo w Manili (co ciekawe dla omawianego w tym artykule tematu - przy współudziale Loyola School of Theology). Jedną z głównych tez była ta, iż „,od czasów II Soboru Watykańskiego, a nawet wcześniej, Kościół katolicki na Filipinach był żywo zaangażowany w [proces] tworzenia się filipińskiego społeczeństwa. Związek ten był wzmacniany podczas lat autorytarnych rządów [Ferdinanda Edralina Marcosa - przyp. M.D.], jak i dziś, w czasach tworzenia demokracji konstytucyjnej"24.

Istnieje wiele przykładów filipińskich widowisk, rytuałów i performansów sakralnych, które doskonale pokazuja jak silnie złączono - nie zawsze świadomie - lokalne tradycje prekolonialne (często animistyczne) z tradycją katolicka, która początkowo została narzucona przez hiszpańskich kolonizatorów, a która dziś uważana jest przez samych Filipińczyków za jeden z podstawowych filarów ich tożsamości narodowej.

Mowa tu między innymi o Ati-Atihan, odbywającym się w każdą trzecią niedzielę stycznia w mieście Kalibo. Ten religijny „festiwal” obecnie odbywa się ku czci Santo Niño (wyobrażenia Jezusa jako Infanta), jednak jego korzenie sięgają czasów przed kolonizacją (ok. XIII w.), gdy tego dnia oddawano cześć animistycznym bogom, określanych zbiorowym terminem Anito (lub Anitu). Podczas Ati-Atihan organizowana jest parada, w trakcie której rozbrzmiewa lokalna muzyka etniczna, a tancerze i aktorzy ubrani są w tradycyjne, bogato zdobione kostiumy. Jednym z najważniejszych momentów Ati-Atihan jest wspólna msza i przyjęcie komunii świętej - co wyraźnie pokazuje, jak doskonale jezuiccy misjonarze potrafili wykorzystać rdzenne tradycje widowiskowo-teatralne w prowadzonym przez siebie procesie chrystianizacyjnym.

Przykładem rozwijającym się w przeciwnym kierunku niż Ati-Atihan są fiesty, organizowane corocznie w każdym barangay (wiosce/miasteczku) ku czci danego patrona-świętego. Jest to tradycja charakterystyczna dla Półwyspu Iberyjskiego, która została zaszczepiona na Filipinach wraz z rozwojem katolicyzmu. Dziś jednak wraz z falą sekularyzacji (najsilniej zauważanej po XX-wiecznej „kolonizacji” przez Stany Zjednoczone), fiesty - choć nie pozbawione religijnych korzeni - stały się wydarzeniem integrującym daną społeczność, okazją do zabawy jedynie $\mathrm{W}$ wymiarze świeckim ${ }^{25}$.

To, co jednak wciąż pozostaje ściśle sakralne, to tradycje pasyjne. Nie bezpodstawnie R. Trexler wskazywał na drogę przekazywania uteatralnionej tradycji pasyjnej, która biegła od Półwyspu Iberyjskiego (wcześniej z Włoch), przez dzisiejszą Amerykę Środkową i Południowa, aż na Filipiny ${ }^{26}$. Trudno zaprzeczyć podobieństwu między iztapalapiańską pasją a cutudowskimi krzyżowaniami ${ }^{27}$ - nie tylko $\mathrm{w}$ ich wymiarze wizualnym, lecz także w kontekście problemów, które implikują i jednocześnie wydobywają na światło dzienne. Krzyżowania i procesje biczowników są

24 J. Mario, C. Francisco, E. C. Lallana, M. M. Ramirez, F. N. Zialcita, Integrative or divise? Christian Symbols and Rituals in Philippine Society, "Pulso Monograph", No. 7, Manila 1991.

25 Por. tamże, s. 21-28.

26 R. C. Trexler, Reliving ..., dz. cyt., s. 143.

27 Krzyżowania, połączone z biczowaniami i odgrywaniem pasji, które corocznie odbywają się w San Fernando Cutud zostały szerzej opisane w referacie, wygłoszonym podczas Talentów 2009. 
często traktowane przez Filipińczyków jako temat tabu ${ }^{28}$. Choć organizowane przy wsparciu rządu, jak i lokalnej wspólnoty katolickiej w San Fernando Cutud (prowincja Pampanga), oficjalnie są krytykowane przez Kościół katolicki na Filipinach. Co istotne, tak samo jak w Meksyku, i tu widać wyraźną granicę między wyższą a niższą klasą społeczna, przekładającą się na celebrowanie zmartwychwstania Chrystusa przez pierwszą i adorowania jego pasyjnej męki i cierpienia przez drugą.

Co niezwykle istotne w tym kontekście, to fakt, iż również inne widowiska sakralne towarzyszące celebrowaniu Semana Santa, najżywiej rozwijane są dziś na prowincji, a nie w głównych metropoliach (jak Metro Manila, czy Davao City). Przykładem tego mogą być tzw. procesje z platformami, na których usytuowane są figury świętych. W miasteczku Morong w prowincji Rizal, w każdą Wielką Środę ma miejsce wydarzenie, przygotowywane przez wiele tygodni przez całą wspólnotę $e^{29}$. Na specjalnie do tego przystosowanych wózkach-platformach umieszczone zostają kilkumetrowe figury świętych i postaci występujących w pasyjnej historii. Za ich pomocą odgrywana zostaje historia Męki i Śmierci Chrystusa podczas kilkugodzinnej procesji, prowadzonej głównymi ulicami Morong. Procesyjność (charakterystyczna dla wielu filipińskich widowisk i rytuałów, mających jeszcze prekolonialne korzenie), wraz z procesem chrystianizacji, prowadzonym przez hiszpańskich jezuitów, została "przełożona” na uplastycznione i uteatralnione przeżywanie nowotestamentowej historii. Wraz z upływem czasu samoistnie została ustanowiona "granica aktywności" tych wydarzeń - najbardziej rozbudowane w formie, a jednocześnie najważniejsze dla lokalnej wspólnoty, okazały się te, które mają miejsce z dala od wielkomiejskiego zgiełku (choćjednocześnie wielu mieszkańców metropolii wyjeżdża w trakcie Wielkiego Tygodnia, na prowincję, by tam głębiej przeżywać ów sakralny czas).

\section{WAYANG WAHYU - BIBLIJNY TEATR CIENIA}

Słowo wayang oznacza w języku indonezyjskim „cien'. Podstawą azjatyckiego teatru wayang ${ }^{30}$ są marionetki (mogą być wykonane ze skóry lub drewna; czasem przedstawiają nie tylko postać, lecz całą scenę rodzajową), a ich cień rzucany jest na podświetlony, kilkumetrowy ekran. Źródeł tej formy teatralnej (która poza Indonezją jest żywo rozwijana m.in. w Malezji czy Tajlandii) upatruje się przede wszystkim w Chinach, Indiach i preindyjskiej Jawie. Na rozwój tej tradycji wpłynął także balijski wayang purwa i turecki karagos ${ }^{31}$. „To w południowo-wschodniej Azji owa forma teatralna jest najbardziej rozpowszechniona i popularna, a na Jawie osiaga szczyt wyrafinowania i może przybrać formę wyszukanej rozrywki dworskiej, z więcej niż czterystoma marionetkami oglądanymi z obydwu stron ekranu i z olbrzymią orkiestrą"32.

$\mathrm{W}$ przypadku wayang wahyu marionetki początkowo były wykonywane z papieru (co zmniejszało koszty wykonania), jednak obecnie wykonuje się je przede wszystkim ze skóry krów i bawołów, odpowiednio nacinanych i perfekcyjnie pokrywanych farbą ${ }^{33}$. Poruszane są przez dhalanga (odpowiedzialnego także za narrację i interpretację przekazywanej widzom hi-

\footnotetext{
28 Na podstawie badań terenowych prowadzonych przeze mnie od listopada 2008 do kwietnia $2009 \mathrm{r}$.

29 Na podstawie badań terenowych przeprowadzonych przeze mnie w Morong w 8. - 9. kwietnia $2009 \mathrm{r}$.

30 Co istotne, najbardziej znany rodzaj indonezyjskiego teatru cieni - wayang kulit - 7. listopada $2003 \mathrm{r}$. został wpisany przez UNESCO na listę Arcydzieło Ustnego i Niematerialnego Dziedzictwa Ludzkości (ang. Masterpiece of Oral and Intangible Heritage of Humanity).

31 M. Smithies, E. Kerdchouay, Nang Talung: the Shadow Theatre of Southern Thailand, "Asian Folklore Studies", vol. 62, 2003, s. 25-64.

32 Por. tamże.

33 Opis na podstawie artykułu M. Popławskiej. Por. M. Poplawska, "Wayang Wahyu” as an Example of Christian Forms of Shadow Theatre, "Asian Theatre Journal" 2004, vol. 21, no. 2.
} 
storii), a ich cień rzucany jest na prostokątny ekran, po którego obu stronach może siedzieć widownia, złożona nie tylko z chrześcijan.

W tworzeniu spektaklu bardzo ważną rolę odgrywa muzyka, nadająca rytm całemu wydarzeniu. Orkiestra (gamelan), złożona często z kilkunastu muzyków, grających na tradycyjnych instrumentach oraz chór kobiet i mężczyzn, stanowią niezbędne elementy każdego przedstawienia.

Od innych azjatyckich teatrów cieni wayang wahyu odróżnia tematyka. Historie przedstawiane przez dhalanga oparte są na motywach ze Starego i Nowego Testamentu - jak pisze Popławska: najpopularniejsze są m.in. historie Samsona i Dalili, Dawida i Goliata, Józefa, Estery, Noego, Izaaka, Daniela, Mojżesza, Jana Chrzciciela, Marii Magdaleny, narodzin i śmierci Jezusa oraz zesłania na apostołów Ducha Świętego ${ }^{34}$. Muzyka zazwyczaj jest zapożyczana z wayang purwa, jednak tekst pieśni należy już do tradycji chrześcijańskiej3. Podobnie jak z publicznością również w kwestii zespołu wyznawana religia nie wpływa na możliwość uczestnictwa. Najistotniejsze są zdolności warsztatowe i artystyczne osób, które tworzą gamelan.

Pomysłodawcą tej nowej, katolickiej formy wayangu był brat Timotheus L. Wignyosoebroto, który w 1957 r. obejrzał spektakl Dawud Mendapat Wahyu Kraton (Dawid doznaje Boskiego objawienia), wykonywanego przez M.M. Atmowijoyo. Wtedy to brat Timotheus zapragnął stworzyć nową wersję wayangu, opartą na Biblii, ze specjalnie zaprojektowanymi marionetkami. 2. lutego 1960 r., w Surakacie, wystawiono Malaikat Mbalelo (Bunt aniołów). W późniejszych latach zawiązała się grupa tworząca i wspierająca rozwój wayang wahyu, a w 1975 r. utworzono specjalne towarzystwo tego teatru ${ }^{36}$.

Wayang wahyu wykonywany jest przede wszystkim z okazji świąt wpisanych w katolicki kalendarz liturgiczny (takich jak: Boże Narodzenie, Wielkanoc - wtedy przedstawienia są także transmitowane w Radio Republik Indonesia, czy w niektórych prywatnych rozgłośniach). Ponadto może być on wykonywany dla uczczenia ważnych uroczystości poszczególnych kościołów, szkól, czy uniwersytetów. Zdarza się, iż przedstawienia odbywają się podczas narodowych i lokalnych festiwali wayang $u^{37}$.

Co ciekawe, podobne zjawisko zaistniało także wśród protestanckiej społeczności, gdzie w $1970 \mathrm{r}$. stworzono wayang prajanjian ${ }^{38}$.

Marzanna Popławska zwraca uwagę na fakt, że wayang wahyu nie mógłby powstać, gdyby nie zmiana polityki Kościoła po II Soborze Watykańskim, kiedy to zmieniło się „wcześniejsze europocentryczne i w znacznym stopniu silnie scentralizowane/uniwersalistyczne nastawienie Kościoła na pluralistyczne i bardziej skupione na lokalności" ${ }^{\prime 39}$.

To właśnie wtedy, w latach sześćdziesiątych, nastąpił proces inkulturacji, a zatem: „wewnętrzne przekształcenie autentycznych wartości kulturowych przez ich integrację w chrześcijaństwie i zakorzenienie chrześcijaństwa w innych kulturach" ${ }^{\prime 40}$. Co istotne „teologia inkulturacji [...] wyznaczyła nową wizję multikulturowego Kościoła katolickiego, zauważając, iż wiara stanie się kulturą jeśli zostanie w pełen sposób przyjęta i przeżyta" ${ }^{\prime 41}$.

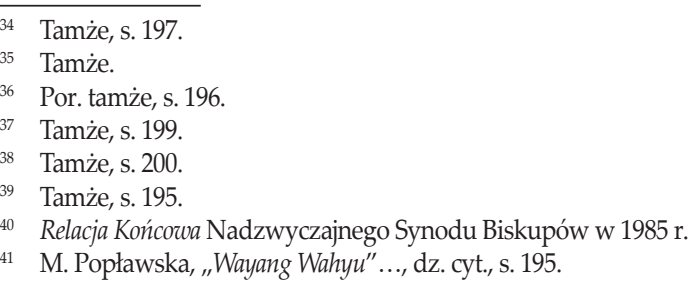


Popławska znakomicie pokazuje zależność między inkulturacją i zmieniającym się obliczem Kościoła katolickiego a rozwojem formy teatralnej. Warto przy tym zaznaczyć, iż wayang wahyu - choć będące jednym z najciekawszych fenomenów XX-wiecznej inkulturacji na terenie Azji Południowo-Wschodniej - nie może być traktowane jako arkadyjska wizja teatru religijnego. Istotne wydaje się pokazanie także szerszego tła społecznego i politycznego w Indonezji, gdzie koegzystencja wielu religii często nie przebiega harmonijnie. Osiemdziesiąt procent Indonezyjczyków wyznaje islam (zarówno w bardzo tolerancyjnej, jak i fanatycznej odmianie), około dwanaście procent stanowią chrześcijanie, a pozostałych kilka to wyznawcy hinduizmu, buddyzmu, czy animizmu. Jak podkreśla ksiądz Józef Glinka „w okresie rządów Suharta, szczególnie w ostatnich 15 latach, spalono lub zniszczono ponad pięćset chrześcijańskich świątyń i innych zabudowań należących do Kościołów. Mimo różnorodnych przejawów dyskryminowania chrześcijan, stale rośnie ich liczba na archipelagu, np. liczba katolików wzrasta co roku o 4,6 proc., głównie w miastach" ${ }^{\prime \prime 2}$.

Należy pamiętać, iż artykuł Popławskiej jest jedną z nielicznych (jeśli nie jedyną) opublikowanych prac naukowych na temat wayang wahyu. W kontekście procesu inkulturacji, powstałej pod wpływem działalności misjonarzy, stanowi ona doskonałą obserwacię tego, iż „wayang wahyu, mimo że w wielu aspektach marginalne [...] jest przykładem żywotności tradycyjnej sztuki na Jawie, która nieustannie znajduje nowe formy dla własnej ekspresji. Jest wciąż rozwijana, prawdopodobnie $w$ kierunkach zaskakujących dla antropologów z początku XX wieku, którzy ubolewali nad nieuchronnym wymieraniem tradycyjnych kultur, spowodowanym wkroczeniem zachodnich religii i misjonarzy ${ }^{\prime \prime 4}$.

\section{Résumé}

Praktyka adaptacji „,miejscowych” zwyczajów jest znana w chrześcijaństwie już od czasów cesarstwa rzymskiego (czego najlepszym przykładem może być ustanowienie Bożego Narodzenia w czasie, gdy odbywały się Saturnalia), jednak niezwykle rzadko zdarza się, by we współczesnych studiach postkolonialnych badano pod tym kątem teatr.

Opisane powyżej przykłady - iztapalapiańska pasja, filipińskie widowiska i performanse sakralne oraz jawajski teatr cieni wayang wahyu - ilustrują nie tylko przemiany, jakie dokonały się pod wpływem działalności misjonarskiej i kolonizacyjnej. Będąc efektem takich zwrotów jak transpozycja paradygmatu teatralnego (dokonana przede wszystkim dzięki jezuitom), czy XX-wieczna inkulturacja, wynikająca z postanowień Soboru Watykańskiego II, stają się pryzmatem, przez który możemy obserwować zarówno historyczną zmianę tworzenia i podejścia do kultury, jak i dzisiejsze rozumienie wiary, potrzebę kontaktu z sacrum poprzez różnorako definiowany teatr (czy też teatralność).

Nie można zapominać o głęboko hybrydycznej naturze omawianych przykładów, której nie uzyskałyby bez wzajemnego przenikania się trzech porządków czasowych (pre-przeszłości, przeszłości, teraźniejszości). Jednocześnie warto skupić się także na dokonywanych w ich obrębie aktualizacji, dostosowywaniu ich do panujących relacji społecznych.

Opisane tu formy, wrastając w tożsamość narodową (jak i lokalną) postkolonialnych państw, stały się formą ekspresji „własnej” kultury i religijności - już nie narzuconej, czy kojarzonej z opresja, choć przecież genetycznie (i historycznie) będącą formą obcą. Dzięki temu procesowi, kultury te w dalszym ciągu się rozwijają - by powtórzyć słowa Popławskiej - na przekór przewidywaniom XX-wiecznych antropologów.

${ }^{42}$ Por. http://www.opoka.org.pl/biblioteka/Z/ZM/indonezja.html, 3.11.2010.

43 M. Popławska, „,Wayang Wahyu”..., dz. cyt., s. 200. 


\section{Bibliografia}

Blond G., Ocean przygody, t. 1 i 2, Warszawa 2008.

Desai G., Nair S. (red.), Postcolonialism. An Anthology of Cultural Theory and Criticism, Oxford 2005.

Gouhier H., Istota teatru. Obecność i teraźniejszość, „Pamiętnik Literacki“ 1976, z. 2.

Lacouture J., Jezuici, t. 1: Zdobywcy, Warszawa 1998.

Lugard F., The Value of British Rule in the Tropics to British Democracy and the Native Races, [w:] G. Desai, S. Nair (red.), Postcolonialism. An Anthology of Cultural Theory and Criticism, Oxford 2005.

Mario J., Francisco C., Lallana E. C., Ramirez M. M., Zialcita F. N., Integrative or divise?

Christian Symbols and Rituals in Philippine Society, "Pulso Monograph", No. 7, Manila 1991.

Popławska M., "Wayang Wahyu” as an Example of Christian Forms of Shadow Theatre, "Asian Theatre Journal” 2004, vol. 21, no. 2 .

Desai G., Nair S. (red.), Postcolonialism. An Anthology of Cultural Theory and Criticism,

Oxford 2005.

Sławińska I., Kaczmarek W., Sulisza W., Stykowa M. B. (red.), Dramat i teatr sakralny, Lublin 1988.

Sławińska I., Dramat i teatr w refleksji teologicznej, [w:] I. Sławińska, W. Kaczmarek, W. Sulisza, M. B. Stykowa (red.), Dramat $i$ teatr sakralny, Lublin 1988.

Smithies M., Kerdchouay E., Nang Talung: the Shadow Theatre of Southern Thailand, "Asian

Folklore Studies" 2003, vol. 62, s. 25-64.

Trexler R. C., Reliving Golgotha. The Passion Play of Iztapalapa, London 2003.

\section{Netografia}

http://www.inside-mexico.com/featuresemana.htm, 8.11.2010.

http://ipsnews.net/interna.asp?idnews=23257, 9.11.2010.

http://www.inside-mexico.com/featuresemana.htm, 8.11.2010.

http://www.opoka.org.pl/biblioteka/Z/ZM/indonezja.html, 3.11.2010.

\section{Słowa kluczowe}

kolonizacja, chrystianizacja, teatralność, misjonarze, inkulturacja, hybrydyczność, iztapalapiańska pasja, filipińskie widowiska sakralne, indonezyjski wayang wahyu

\section{STRESZCZENIE}

Artykuł porusza temat procesu kolonizacji i chrystianizacji, prowadzonej przez europejskich misjonarzy od czasu tzw. „wielkich odkryć geograficznych”. Celem nie jest jednak opisanie historii kolonizacji, lecz spojrzenie na dzisiejsze oblicze artystyczno-sakralnych działań, obecnych w postkolonialnym świecie.

Opisane zostały przykłady współczesnych widowisk i performansów sakralnych w Iztapalapie (Meksyk), na Filipinach (prowincje: Aklan, Pampanga, Rizal) oraz jawajski teatr cieni wayang wahyu. Ich charakter należy odczytywać jako hybrydyczny, a zatem taki, który nigdy nie powstałby bez prekolonialnych korzeni, kolonizacyjno-chrystianizacyjnej działalności misjonarzy oraz postkolonialnego Nowego Porządku.

\section{The processes of Colonization and Christianization and The theatre - THE OVERVIEW FROM $20^{\text {TH }}$ AND $21^{\text {ST }}$ CENTURY PERSPECTIVE}

\section{Keywords}

Colonization, Christianization, theatricality, missionaries, enculturation, hybridity, The Passion Play of Iztapalapa, Philippine religious shows, Indonesian wayang wahyu 


\section{Summary}

The article discusses the issue of colonization and Christianization processes conducted by European missionaries from the time of so-called "Age of Discovery". However, the aim of the article is not creating a description of colonization history, but taking a look at today's vision of artistic and religious activities present in postcolonial world.

In the article there were described examples of religious shows and performances in Iztapalapa (Mexico) and Philippines (provinces: Aklan, Pampanga, Rizal) as well as Java shadow play called wayang wahyu. Character of these forms of art should be defined as hybrid - they would not exist without pre-colonial origins, colonization- and Christianization-related activities of missionaries and postcolonial New World Order. 